\title{
Political Activity of Citizens as a Stipulation for a Civil Society Development
}

\author{
Elena Mitskaya ${ }^{1}$ \\ ${ }^{1}$ South Kazakhstan Pedagogical University, Shymkent, Kazakhstan \\ ${ }^{2}$ South Kazakhstan State University named after M.O. Auezov, Shymkent, Kazakhstan \\ ${ }^{3}$ Saint Petersburg Institute of Law, Saint Petersburg, Russia \\ Correspondence: Elena Mitskaya. E-mail: sergey.kulish@inbox.ru
}

Received: November 13, 2016

Accepted: January 4, 2017 Online Published: January 19, 2017

doi:10.5539/ass.v13n2p 88

URL: http://dx.doi.org/10.5539/ass.v13n2p88

\begin{abstract}
In this article the author examines the dynamics of changes in the implementation of political rights of the citizens of Kazakhstan, and specifically the right to choose from the beginning of its independence and sovereignty, and to the present. Freedom and the desire of citizens of Kazakhstan to develop direct democracy is directly dependent on how much the person is not only aware of itself as an active, self-realized person, but is relevant to this socio-political, economic and other conditions. Conditions of occurrence and development of civil society is social freedom, democratic governance, the existence of a public sphere of politics and political discussions. The author proves the relationship of civil society and development of the active implementation of the political rights of citizens. In the political sphere, the degree of freedom of society is determined by the level of development of democracy in the country and warranty democracy as a whole and of each of the political right in particular. The degree of force activity of citizens in the implementation of political rights is the example of Kyrgyzstan. The gradual transition from passive participation of citizens in a democracy to active is a natural phenomenon, not only for Kazakhstan, but also a number of post-Soviet countries, which is shown in the example of the Russian Federation. The author concludes that Kazakhstan has gone through a period when citizens remained passive in exercising their political rights. Now the citizens of Kazakhstan are actively participate in the process of democracy, indicating a high degree of development of Kazakhstan's civil society.
\end{abstract}

Keywords: civil position, human rights, political rights, political activity, right to choose

\section{Introduction}

The existing theories of civil law give an opportunity to compare different points of view, opinions concerning the essence of the civil society (Matyuhin, 2000). Basing on them, we can reveal the concept of a civil society as following: a civil society is a community of self-governing social institutions and relations and its purpose is to provide person's priority in the society. That is, a civil society is the highest stage of a society development where a person is most important as an active, self-realizing personality. Social activity, however, understood as "a characteristic of a social subject, manifested through self-activity" (Kozhevnikov, 1991), has its varieties out of which we would like to draw the reader's attention to the political activity targeted to the progressive development of the society and state that is absolutely important.

Conditions of rise and development of a civil society include social freedom, democratic government, existence of social sphere of political activity and political discussions. Socio-political sphere of a civil society covers civil society and political organizations and movements, different forms of citizens' activity, local self-governing bodies. Thus, social organizations achieve their purposes by covering many spheres of public life. They influence molding of public opinion which, according to J. Bryce is made out by few, but then is consolidated by activity of many people (Bryce, 1921). Social organizations develop political culture of the citizens and contribute to their political education. Besides, they allow revealing and substantiating interests of most social groups. It is social organizations which are able to provide permanent connection between the civil society and the state (Avakyan, 1996).

Hence, a civil society as V. A. Zatonskii fairly stresses "cannot function without active autonomous subject" (Zatonskii, 2006). And the state actually interacts with the most active part of the civil society. At the same time, 
they must be not only active but also politically and juridically educated cultured people with high sense of civic duty, active legal consciousness, who shape their behavior according to law and morality (Zatonskii, 2006).

Political activity can be focused both on the traditions and values of the past and the future, embracing new ways to change and growth. Political activity can be creative and destructive, purposeful and spontaneous. A base for an individual's political activity is first of all social freedom. And of course, the degree of freedom for every member of the society is defined by the freedom of the society itself, (to delete comma) that is, a man can have a greater degree of freedom only when the society is free. Freedom of the society in its turn is defined in terms of the level of development of the society in socio-economic, political, cultural spheres. Accordingly, in the political sphere, the degree of freedom of society is determined by the level of development of democracy in the country and assurance of democracy as a whole and each political right in particular.

As is known, the basis of democracy constitutes the political rights and freedoms of citizens. Some researchers, speaking about political rights and freedoms, distinguish "constitutional" rights and freedoms of citizens and "basic" ones. In literature the constitutional rights and freedoms of a man and a citizen are understood as these subjects' rights and freedoms secured by the Constitution. In its turn, the Constitution fixes not an arbitrary set of rights and freedoms, but only those that are most essential for an individual and a state in their relations that is basic rights and freedoms. Hence, the term "basic" stresses the contents of these rights and freedoms while the term "constitutional" stresses the fact that they are secured by the Constitution. Other researchers do not make this distinction (Vitruk, 1685). Besides, we should point out the reasons, due to which some rights and freedoms are secured by constitutions, and others in active legislation.

Thus, N. L. Granat has all the grounds to state that the reasons to secure rights and freedoms in the Constitution are: 1) significance of these rights and freedoms for a man and a society; 2) primordial, innate and unalienable nature of the rights and freedoms belonging to a man; 3) leadership of the constitutional (basic) rights and freedoms which makes all other rights and freedoms in a particular sphere of life (labor, social, etc.) derived ones; 4) basic rights and freedoms belonging to every man or every citizen; 5) generality of the basic rights, freedoms and responsibilities, that is their equality and unity for everyone with no exception accordingly for every person or for every citizen; 6) impossibility to acquire or alienate the basic rights, freedoms and responsibilities in a citizen's own will; 7) the basic rights, freedoms and responsibilities are valid across all the country (Granat, 1996).

In our opinion, constitutional rights and freedoms of personality are the basic rights and freedoms secured in the Constitution corresponding to the generally recognized principles and norms of the international law and most essential for the state and a person.

In general the system of political rights and freedoms of citizens consists of two interconnected subsystems including the rights of citizens containing the authority to participate in organization and activity of state and its bodies and the authorities which are unalienable rights of citizens concerning their active participation in the society's life.

Political rights and freedoms as subjective rights and freedoms of citizens consist of the following:

- the right to act positively (as a possibility of an authorized person to implement juridically significant actions by oneself);

- the legal claim (as a possibility of an authorized person to demand implementation or observation of a juridical responsibility);

- the assertion of right (as a possibility to put into action the state coercion mechanism against the responsible person) (Alekseev, 1982).

For example, the actual authority for positive action of the active election legislation is manifested by the possibility to study the lists of electors, to discuss the program of a candidate for deputy, to take part in an election campaign. This is the right to vote itself. The active electoral law includes a number of competences to demand implementation or observation of a legal duty from the person responsible for it. In particular, for example, the voters have the right to demand that the election committees should conduct the election in accordance with the law (taking in to considerations the terms of agitation for the candidates, including in the elector's lists, etc.). Authority for one's own positive actions to implement the freedom of speech is the possibility to spread one's own opinion in any legal form. The legal claim of this particular political freedom is expressed in a citizen's demand not to hamper implementing the authority for one's own positive actions, the requirement addressed to the governmental bodies and officials to spread objective information concerning the events in the country. 
The soviet statehood science paid attention and researched the problems connected with political activity. Orzikh M., Maslennikov V., Kuchinsky V., Zheleznov B., Kopeichikov V., Bondarev N., Klyuev A. (Klyuev, 1986) were interested in structural aspects of political activity. Cherednichenko A. divided political activity into organizational, theoretical, upbringing, executive, managerial (Cherednichenko, 1986). Kovler A. and Smirnov V. wrote about different types of political participation: individual and collective, voluntary and coercion, active and passive, traditional and alternative, revolutionary and protective (Kovler, 1986). Fedoseyev A. analyzed structural peculiarities of political ideology and psychology, political norms, values, institutions, relations, processes and behavior (Fedoseyev, 1974). Shapiro V. revealed structural peculiarities of obtaining political knowledge as well as political decisions developing, making and implementing (Shapiro, 1983). Despite the fact that these research reflect peculiarities of the political regime of the state existing in that period they haven't lost their importance today.

Like the election of the deputies to the legislative assembly of Kirgizstan showed in early 2005 the electors were passive. Eleven constituencies were established in the country, and the number of absentees was $50 \%$ to $83 \%$ of the total list of electors (Isaev \& Seyitbaev, 2006). Though, as we know from examples of other countries electors could be involved in the election process legislatively. An example of legislative measures to attract electors to the election process can be mandatory voting consolidated in some Constitutions. Public reprimand or fine is applied as sanctions while evading the execution of such obligations. For example, in Turkey the fine is 13 times as much as in Egypt, but almost seven times as less as in Luxemburg (Chirkin, 2005).

As a matter of fact, the fear to be fined or blamed in non-patriotic behavior in public will help make the electors more active. At the same time, one can doubt that kind of obligation will guarantee 100 per cent attendance of the polling stations. In Kirgizstan the official recognition of the election when the results were forged, people's poverty, unemployment, corruption of all state structures led to revolutionary explosion. The country was gripped by demonstrations and disobedience actions, government agencies were captured and government of the people was established in some areas of the country. People's revolution won in Kirgizstan on March 24, 2005 (Isaev \& Seyitbaev, 2006). Thus, analyzing political activity in this example, one can say that the political activity was both purposeful (to topple Akaev's regime and to elect a new government capable of leading the country out of crisis) and spontaneous (storming the House of Government). It was voluntary, active and revolutionary political participation of the people in governing state affairs and implementation of the right to take a choice, but in fact after the election was conducted. It was an action of people's power. The point is that the events which took place in Kirgizstan confirm the researchers' data that the political activity is based, besides the abovementioned, first of all, on the interest that arises in man to certain actions on his part. That is, the source of political activity is legal interest which shapes stable spiritual orientation to the values of political and legal culture (Malko, 2005). Secondly, political activity is based on the conviction that a one's political participation is efficient.

Interesting data were received by the Institute of Electoral Systems Development of the Russian Federation. The institute conducted a research, the results of which showed that only 6-9 per cent of the people in the Russian Federation were sure that the expression of their will as voters would be efficient (Kuzmin, 2003). The results received at the Institute of Development of Kazakhstan in April 1996 were not less interesting: confidence in local authorities was expressed only $24.7 \%$ of respondents in Eastern Kazakhstan Region, 20,3\% of respondents in Northern Kazakhstan Region, 2.8\% of respondents in Atyrau Region (Karin, 1999). Though, these data are 20-year old they give an opportunity to compare the degree of people's confidence in the authorities today. In addition, the results of the above studies support the idea that there is no doubt that the problem of voting activity by legislative decision obliging will not solve the problem of lack of faith in the efficacy of the election results. In our opinion, the problem of disbelief in efficiency of the election results lies in people's disbelief in government institutions, infringement of the legality during the election process.

Increased political activity by improving the legal interest of citizens to the electoral process and formation of a stable belief in the effectiveness of its participation in them is a problem specific to the post-Soviet region. For example, Zatonskii V. analyzing the electoral process at the beginning of the development of post-Soviet Russia pointed out the fact that the trend of non-performance of their duties by the members of precinct election commissions enhanced (Zatonskii, 2006). The problem of bribing electors was important as well. For example, the electioneer offers to vote for his candidate trying to sincerely convince the electors that they will make the right choice doing so and promising some material reward at the expense of future voting or direct bribing when the electors are offered a certain sum of money for their voting on the day of election. Or when the electors refuse to vote unless they have their roof repair or running water or gas pipe installed in their houses. Vishnevsky L. points out five technologies to bribe electors (Vishnevsky). 
Kazakhstan in this regard was no exception only 10 years ago (Demographic monitoring). It was common knowledge that sometimes free concerts, distribution of sausages and free medications were used to bribe electors (Astana). The Law on elections in the Republic of Kazakhstan prohibits it (article 27). This Law also prohibits to give or to promise money or free or preferential goods or services, bonds and securities to the electors. The exception is free printed materials, badges, flags and other signs and symbols especially made for the election campaign. Compare the legislation of the Russian Federation: candidates and their authorized representatives are not allowed to give electors' valuable things (the exception is reward for organizational work), to sell goods (except printed materials and badges specially made for election campaign). Consequently, the legislation of the Russian Federation refers to the varieties of bribing voters the following actions: free concerts, distribution of goods, souvenirs, food and valuable gifts on behalf of the candidate.

This year, a number of violations were identified by observers during the election of deputies of the South Kazakhstan regional Maslikhat from $21^{\text {st }}$ Sharaphaninskiy constituency of Kazygurt district. In particular, at Zhanabazar polling station observers filmed on video numerous instances of multiple voting of the same people without presenting identification documents. At M. Auezov polling station during the vote count was found exceeding the number of ballots at 201 apiece with respect to the amount that was issued by the polling station. This is a violation of article 37 of the Law "On elections in the Repuplic of Kazakhstan". During the vote count at an Akzhar polling station the light turned off and at that moment a stranger put a ballot paper in a ballot box. During further ballots counting there were found exceeding quantity of ballots to 137 units relative to the number issued by the polling station. And finally, violations of three articles $(39,41$ and 43$)$ of the Law "On elections in the Republic of Kazakshstan" were reported at Rabat polling station. Observers videotape voting by unauthorized people, as well as the same people voting several times, receiving ballots (about twenty) and vote for one person once more. In addition, the protocol of the commission of the polling station did not indicate the number of citizens who participated in the vote, but only the number of ballots issued by the commission members (Lawlessness). We draw attention to the fact that the irregularities in the election process in Kazakhstan were not found for the first time by OSCE (Business Week). However, along with the disadvantages there are positive moment observed, in particular, it is noted the effectiveness of the organization of extra-parliamentary elections in March 2016 (OSCE). Social freedom of society, as we already mentioned, is determined by the level of development of the society as a socio-economic, political and cultural spheres, and this means that interest in the electoral process and the belief in the effectiveness of participation of citizens are directly dependent on how strongly the country's population will be confident in their social and legal protection from the state, every worker really feel the improvement of the living standards of their own and the country as a whole. And the economic well-being for such a multinational state like Kazakhstan is a must. The decline in unemployment, improving living standards will loosen every social tension and preserve calm inter-ethnic relations in the country because the nature of ethnic relations in the country affected by socio-economic factors of development (Aminov \& Kalmykov, 1996). The final voter turnout in non-parliamentary elections in Kazakhstan amounted to $77.1 \%$ in March 2016. This figure exceeded the similar results of previous parliamentary campaigns. Thus, the total voter turnout was $75.45 \%$ in the Majilis of the 2012 and 2007 elections $64.56 \%$ (Elections). The figures speak for themselves and are evidences of increasing interest of the people in the institutions of power. So, if in 2009 the researchers said that there are "patterns of electoral behavior of Kazakhstan, is very active in the presidential election less than in the parliamentary elections, and a very low activity in the elections of local importance" (Bokaev, 2009), currently, one can say with full confidence that the people of Kazakhstan have become more active to embody their right to vote. Active citizen participation in democracy is enhanced.

It is believed that the evolution in Kazakhstan is what it is and the country goes its own way (Kurtov, 2000). In any country, public confidence in the authorities can gradually return when democracy is warranted. Currently, the country has system guarantees of democratic elections. Illegal interference of the executive power, the threat of bureaucratic, administrative and legal harassment of the media, artificially created difficulties for the opposition parties and candidates and intimidating them during election campaigns, and other disorders that do not confirm that the elections were free and fair, and together with the power and corruption of the past remains in Kazakhstan.

Non-governmental organizations are more actively incorporated into the political process every year (Abisheva, 2006). The functioning of political parties and various associations are the evidence that the Kazakh society in the establishment of a truly civil society and the process of civil society development continues.

On the eve of the election of the President of the Republic of Kazakhstan in 2005, the Association of Sociologists and Political Scientists of Kazakhstan has announced the results of a poll: 55\% of respondents is believe that Kazakhstan needs order not a democracy, $54.3 \%$ were in favor of a strong state power, democracy 
was supported by $24.9 \%$ and the total democracy had $12 \%$ (Zheti kyn). You can make the assumption that the most likely here was an expression of the desire of the people to live in a democratic country with a strong power, guaranteeing protection of the rights and freedoms of man and citizen, social security, democratic order. Otherwise, how can be a constitutional declaration of Kazakhstan as democratic, secular, legal, social state. On the eve of the election of the President of the Republic of Kazakhstan for a year ahead of schedule in 2015, according to a survey conducted by NIA "Institute for Democracy," 97\% of Kazakhstan expressed their satisfaction and approval of the Assembly of People of Kazakhstan's initiative on early presidential elections. 95\% believed that the presidential elections will unite Kazakh society during the global economic crisis (Zheti kyn). As a result, according to the Central Election Commission of the Republic of Kazakhstan turnout at the early presidential elections in Kazakhstan amounted to more than 95\% (Shapiro, 1983).

This suggests, the problems of citizen's active political participation (particularly, in elections) and increasing their political activities can be decided in general by strengthening legality and consequently by improving election legislation, citizen's self-consciousness, developing high political culture and sense of civic duty. Moral values are the core of self-consciousness, political culture and sense of civic duty. We should agree that Ilyin I., a well-known lawyer and philosopher expressed his opinion quite precisely when he said: "If inside is malicious, greedily, then no external form, no ban, no thereat, no "election law" will be of any help" (Zvyagintsev, 2007). And, of course, progressive development of three sectors of civil society - economy, democracy and spirituality, based on the individual's freedom - is necessary.

The main thing is that the fundamentals of citizen's political participation in governing the affairs of the state and society that is political rights and freedoms, are consolidated in the Constitution. They correspond to the recognized principles and norms of the international law. The legislation is being improved in the field of widening the mechanisms of its realization. At the same time, we should not forget that state and the society cannot be considered in isolation. The structure of a civil society's political activity has been derived from hierarchy organization of power, a variety of the elements of a political system. In general, the structure of the political activity is divided into public political activity and political activity of civil society.

Kazakhstan has experienced a time when citizens remained passive in exercising their constitutionally guaranteed political rights of the Republic of Kazakhstan. Now the citizens of Kazakhstan are take an active part in the process of democracy, indicating a high degree of development of Kazakhstan's civil society.

\section{References}

Avakyan, S. A. (1996). Political pluralism and social movements in the Russian Federation: The constitutional and legal framework. Moscow.

Alekseev, S. S. (1982). General Theory of Law. Moscow.

Astana candidates handing sausage and medicines. Retrieved from http://www.panarchiv.h15.ru

Aminov, M., \& Kalmykov, S. (1997). Trends in the development of ethno-social relations in Kazakhstan. Sayasat.

Abisheva, M. (2006). Recipes democracy: Kazakhstan version.

Bryce, J. (1921). Modern Democracles (Vol. 2). London.

Business Week. (1999). Standards of democracy do not match. Retrieved from http://newskaz.ru/politics/20160321/11401977.html

Bokaev, S. O. (2009). Political technologies as a factor in the formation of public opinion and electoral behavior: world experience and Kazakhstan. Almaty.

Cherednichenko, A. (1986). Culture of active political action. Moscow.

Chirkin, V. E. (2005). Public authority. Moscow.

Demographic monitoring. Retrieved from http://www.politikas.kiev.ua/articles/6/ item/2005

Elections in Kazakhstan ended with a record turnout and without violations. Retrieved from http://www.zakon.kz/4781841-vybory-v-kazakhstane-zavershilis-s.html

Fedoseyev, A. (1974). Politics as an object of sociological analysis. St. Petersburg.

Granat, N. P. (1996). Constitutional basis of the provisions of human and civil / constitutional rights. Moscow.

Isaev, K., \& Seyitbaev, B. (2006). Features of electoral behavior after the elections. Bulletin of the Karaganda University, 126. 
Kozhevnikov, S. N. (1991). Socio-legal activity of the person and the conditions for its effectiveness: Doctor of Juridical Science. Moscow.

Klyuev, A. (1986). The socialist government: experience and development trends. Moscow.

Kovler, A., \& Smirnov. (1986). Democracy and participation in politics. Moscow.

Kuzmin, V. (2003, November 4). We go together, but we do not trust. At the elections, voters will be active and captious. The Russian newspaper.

Karin, I. Internal political aspects of national security in Kazakhstan. Retrieved from http://www.ca-c.org/journal/cac-04-1999/st-12-karin.shtm/\#1

Kurtov, A. (2000). Elections democracy in Kazakhstan: Authoritarian evolution. Constitutional Law: East European Review.

Law of the Republic of Kazakhstan. On Elections in the Republic of Kazakhstan. http://www.online.zakon.kz

Lawlessness: some electoral commissions of SKR ignored the call of the Elbasy. http://www.camonitor.kz/

Matyuhin, A. A. (2000). The State in the field of law: an institutional approach. Almaty.

Medushevsky, A. N. (1991). Political sociology and history. Novosibirsk.

Maksimov, S. I. (2002). Legal reality: experience of philosophical reflection. Kharkov.

Malko, A. V. (2005). Incentives and restrictions on the right. Moscow.

OSCE / ODIHR mission noted the effectiveness of the organization of elections in Kazakhstan, but points to a number of shortcomings.

https://www.kt.kz/rus/politics/missija_bdipchobse_otmechaet_effektivnostj_organizacii_viborov_v_kazahstane_ no_ukazivaet_na_rjad_nedostatkov_1153618559.html

Shapiro, B. (1983). Social activity of older people in the USSR. Moscow.

Spiridonov, L. I. (1996). Theory of Government and Rights. Moscow.

Shapiro, I. (1992). Democracy and Civil Society.

The turnout in the elections of the President of the Republic of Kazakhstan amounted to more than 95\%. https://www.kt.kz/rus/state/javka_izbiratelej_na_viborah_prezidenta_rk_sostavila_bolee_95_1153603234.ht $\mathrm{ml}$

Vitruk, N. V. (1985). The legal status of the individual in the USSR. Moscow.

Vishnevsky, L. Five bribing voters technologies. Retrieved from http://www.democracu.ru/library/pratice/media.

Zatonskii, V. A. (2006). The efficiency of public. Moscow.

Zheti kyn. http://www.khabar.kz/ru/arkhiv/programmy/ zheti-k-n/item/14789-zheti-kun-22022015

Zvyagintsev, A. (2007, February 21). Law and Spirituality. Arguments and Facts, p. A14.

\section{Copyrights}

Copyright for this article is retained by the author(s), with first publication rights granted to the journal.

This is an open-access article distributed under the terms and conditions of the Creative Commons Attribution license (http://creativecommons.org/licenses/by/4.0/). 